DOI: 10.1515/rpp-2015-0019

Doctor of Pedagogical Sciences, Full Professor NATALIYA MUKAN

National University Lviv Polytechnic, Ukraine

Address: 12 Stepan Bandera St., Lviv, 79013, Ukraine

E-mail: nmukan@polynet.lviv.ua

PhD in Pedagogical Sciences, Assistant Professor MARIANNA HAVRYLYUK

National University Lviv Polytechnic, Ukraine Address: 12 Stepan Bandera St., Lviv, 79013, Ukraine

E-mail: marihor02@mail.ru

Instructor, LESIA STOLYARCHUK

National University Lviv Polytechnic, Ukraine

Address: 12 Stepan Bandera St., Lviv, 79013, Ukraine

E-mail: lesia.stelmakh@gmail.com

\title{
THEORETICAL FRAMEWORK OF \\ LEADERSHIP IN HIGHER EDUCATION OF ENGLAND AND WALES
}

\begin{abstract}
In the article the theoretical framework of leadership in higher education of England and Wales has been studied. The main objectives of the article are defined as analysis of scientific and pedagogical literature, which highlights different aspects of the problem under research; characteristic of the theoretical fundamentals of educational leadership, and presentation of classification of leadership models in educational sphere. Leadership in higher education has been studied by foreign and domestic scientists: methodology of comparative education (C. Bargh, N. Bidyuk, N. Mukan, A. Sbruyeva); continuous professional education (J. Barge, A. Kuzminskyy, N. Nychkalo, P. Lorange); leadership in education (J. Bareham, L. Danylenko, L. Karamushka, N. Kolominskyy, O. Marmaza); leaders' training (A. Borysova, V. Hromovyy) etc. In Ukraine this problem has not been studied yet. The research methodology comprises theoretical (comparative and historical method, logical method, analysis and synthesis), and applied (conversations and dialogues) methods. The research results have been presented: the comprehensive integration of leadership theories in the sphere of philosophy, sociology, psychology, pedagogy, management has been justified; the definition of leadership and distributed leadership, and their characteristic have been provided; the leadership models in higher education of England and Wales have been determined.

Key words: theoretical framework, leadership, leadership theories, leadership models, distributed leadership, higher education, leader, follower, England, Wales.

\section{INTRODUCTION}

At the beginning of the $21^{\text {st }}$ century, special attention is paid to the role of the university in the knowledge society. New technologies, expansion of the students' age category, globalization of educational market and increased competition among universities, transformation of employment types, the priority and practicality of knowledge create a background for implementing university staff leadership in England and Wales, whose main purpose is the realization of staff potential to fulfill the strategic goals of the
\end{abstract}


educational institution. Requirements for teaching and research activities of the university are growing and university staff leadership contributes to the improvement of systems, structures, processes, culture, expertise and networks to ensure its efficient performance.

Leading universities of England and Wales are not only research and educational organizations, they are centers of innovation directing its activities to the commercialization of research and interdisciplinary knowledge sharing, innovation in economic and social spheres; cooperation with various organizations and institutions at regional, national and international levels as well, etc. Functioning of higher education in England and Wales rests on the introduction of a range of innovations in managerial, research and teaching activities, based on the extensive use of leadership potential. Therefore, the theoretical and practical experience of English and Walsh universities deserves attention and requires objective study.

In Ukraine the development of higher education is carried out in accordance with the European integration processes. However, the phenomenon of leadership is underdeveloped, even in the higher educational establishments that have always been bearers of progressive ideas in the national educational sphere. Consequently, their presentday task is to develop leadership skills of university staff and to use leadership potential in managerial, research and teaching activities.

A review of the research literature and the results of the conducted analysis on the peculiarities of university staff performance at national universities enabled us to reveal contradictions between: challenges of the modern knowledge economy and inability of universities to perform society-assigned functions; existing traditional approaches used in managerial, teaching and research work of the university, and the need for their improvement on the basis of leadership potential.

The topicality and insufficient elaboration of the problem in the domestic pedagogical science determined the choice of our research theme.

THE AIM OF THE STUDY

The study of theoretical framework of leadership in higher education of England and Wales is the research aim. The authors have defined the following objectives: 1) to conduct the analysis of scientific and pedagogical literature, which highlights different aspects of the problem under research, 2) to characterize the theoretical fundamentals of educational leadership in England and Wales, and 3) to present the classification of leadership models in educational sphere.

\section{THEORETICAL FRAMEWORK AND RESEARCH METHODS}

The theoretical and methodological fundamentals of our research are the following: the theses of modern philosophy of education (V. Andrushchenko, S. Graham, T. Huston, V. Kremen, I. Zyazyun,); methodology of comparative education (C. Bargh, N. Bidyuk, T. Desyatov, N. Mukan, Y. Neumann, L. Pukhovska, A. Sbruyeva); continuous professional education (J. Barge, A. Kuzminskyy, N. Nychkalo, P. Lorange); leadership in education (J. Bareham, L. Danylenko, L. Karamushka, P. Knowles, N. Kolominskyy, O. Marmaza, H. Syrotenko, K. Ushakov) and leaders' training (A. Borysova, V. Hromovyy, O. Zhyhlo).

During the last decades, comparative education and leadership in educational sphere have been a matter of scientific and practical concern of foreign scientists (S. Ambrose, J. Bocock, P. Eckel, R. Gomes, S. Graham, S. Michael, J. Montgomery, J. Murry, G. Musambira, E. Neumann, M. Norman, J. Snyder) who have studied peculiarities of university staff leadership development in different countries. 
In our research, the scientific papers of Ukrainian scholars (N. Avshenyuk, Ya. Belmaz, N. Bidyuk, H. Byhar, O. Demchenko, Yu. Kishchenko, T. Koshmanova, O. Leontyeva, M. Leshchenko, N. Moros, L. Pukhovska, A. Sbruyeva, S. Synenko, O. Zabolotna, I. Zadorozhna etc.) in the field of comparative education are very important. Some aspects of leadership in education and its realization in the system of higher education of England and Wales have been studied by V. Bazurina, M. Havrylyuk, Z. Mahdach, N. Mukan, I. Myskiv.

Different theoretical and applied research methods have been used in our study. The comparative and historical methods have been used to study educational documents, normative and legislative frameworks of higher education in England and Wales, scientific and pedagogical literature, academic plans and programmes of leadership development of university staff. Logical method has been used to single out the basic concepts of leadership in education; induction and deduction - to formulate the statements and generalize the theoretical and matter-of-fact material; analysis and synthesis - to study theories, concepts and approaches to leadership in educational sphere. Among applied methods, we have used conversations and dialogues with the heads of departments of universities in England and Wales for gathering primary pedagogical information.

\section{RESULTS}

At the beginning of the $21^{\text {st }}$ century, leadership is considered to be a strategic factor in the development of civilization and its main wealth, which is human capital, so the problem of leadership occupies an essential place in the research that testifies its importance and existence in various spheres of human activity. The problem of leadership is reflected in the works of scientists of different disciplines: management, psychology, political science, sociology, philosophy, pedagogy, etc. The application of diverse approaches to determine the content and prospects of examining the concept of "leadership" causes general discussion of various leadership theories. In the process of comparative analysis we identified the unified definition of leadership in higher education to avoid discrepancies in terminology. Leadership in higher education is interpreted as applying leaders' influence to followers, efficient use of available resources, systems and procedures to meet the objectives of the university and execution of its tasks. Its implementation involves attracting numerous university staff to manage the development of university education in order to ensure the leading role of the university in the knowledge society.

For a long period of time leadership has been developing and taking various forms: leader centered, personality centered, hierarchical concepts (which reflected universal characteristics and emphasized the power over the followers) and process centered, collective, contextual, non-hierarchical, shared leadership models.

The analysis of scientific literature gave us the possibility to distinguish different leadership theories and their main forms: trait theories (Stogdill, 1957), (Méndez-Morse, 1992), (Ackoff, 2000), (theory of charismatic leadership as one of the forms); behavioral theories (Stogdill \& Coons, 1957), (Blake \& Mouton, 1972), (McGregor, 2005), (Ramsden, 1998) (autocratic, democratic approach to leadership implementation and non-interference approach); theory of leadership power and influence (Weber, 1997), (Heifetz, 2007), (Yukl, 1999) (legitimate power, influence of reward, coercion, expert authority); leadership situational theory (Fiedler, 1987), (Hersey \& Blanchard, 2007) (situational leadership); cognitive theory (Fiedler \& Garcia, 1987) (leadership is socially conditioned, cognitive processes influence the perception of leaders and leadership); leadership culture theory (Bolman \& Deal, 2008); social change theory (House \& Dessler, 1974), (Manz \& Sims, 
1980) (transactional leadership and transformative leadership as the main forms); chaos theory (Astin \& Astin, 1998), (Ferren, 2004) (perception of leadership as the pyramid of values and moral qualities, leadership is distributed, and its effectiveness is determined by the emotional potential of a person, the ability to collegiate collaboration, the ability to combine entrepreneurship, responsibility and globalization in educational leadership; participative leadership).

According to our research, various approaches to studying the phenomenon of leadership in higher education of England and Wales are distinguished. H. Gunter specifies the following: critical approach (introducing leaders and their followers considering social injustice and resistance to the established power hierarchy); humanistic approach (collecting and propagandizing the theory developed on the basis of famous leaders and managers' experience and biographies); instrumental approach (providing leaders with effective leadership strategies to achieve organizational goals); scientific approach (abstracting and investigating the impact of leadership on the efficiency of organization performance) (Gunter, 2001).

The main functions of leadership in higher education of England and Wales have been defined: determining the general direction (vision of the future, developing strategies for implementing changes to achieve goals); organizing staff work (discussing the vision and strategy, the impact on the formation of teams that accept argumentation purposes); motivation and inspiration (supporting people in overcoming obstacles, satisfying human needs); introducing positive, sometimes dramatic changes.

On the basis of literature analysis, it has been concluded that in higher education of England and Wales the distributed leadership have been used. Despite different approaches to the definition of "distributed leadership", three main aspects are emphasized. Firstly, leadership is a derivative quality of people cooperating with each other. Secondly, leadership is characterized by openness, i.e. possibility to occur both inside and outside the organization. Finally, the experience of leadership is distributed among a large number of people. For this reason, distributed leadership should be regarded as a dynamic, inclusive, collegial process that occurs in a particular context, requires prospects of being spread throughout the system of organization and beyond it.

Distributed leadership in higher education of England and Wales implies:

- widespread involvement of a large number of people: students, pedagogues, support staff, members of public organizations, politicians in the sphere of education, managers of different managerial levels, etc;

- transforming leadership role according to the situation, objectives, experience;

- participation of a considerable number of employees in educational organizations in management and leadership processes.

The theory of distributed leadership involves its implementation on the basis of the potential of all organization members, regardless of their position and responsibility, influence among colleagues, and thus on the overall direction of the organization. The basis for this approach is formed by the sociological and political science theories along with traditional management theories since the concept of organizational culture, organizational climate and contextual nature of leadership are taken into account.

The analysis of scientific literature (Leithwood \& Levin, 2005) and documents of higher education institutions of England and Wales testifies that different leadership models have been used in higher education. Among them we differentiate:

- instructional leadership (focus on the behavior of pedagogues involved in activities that directly affect students' learning); 
- transformative leadership (focus on readiness, commitment and ability of its members to participate in additional activities for the development and improvement of the organization);

- moral leadership (focus on ethics and values, which leaders use in decisionmaking and conflict resolution);

- participative leadership (focus on the process of group decision making, pedagogues' leadership, distributed leadership);

- managerial and strategic leadership (focus on the tasks and functions described in the classical literature in management, coordination, planning, monitoring, resource allocation).

The application of leadership potential in higher education of England and Wales is the subject of comparative pedagogical studies, which illustrate the following: the peculiarities of leadership development; competency characteristic of leader-manager, leader-scholar, leader- pedagogue; leaders' training programs in terms of higher education; involvement of university staff in leadership; leadership in shaping the development strategy of the university, collegial and motivational leadership; development of the culture of research and teaching activities; development of the professional community of university staff and the use of leadership potential for professional development.

Domestic and foreign scholars explore various aspects of the leadership phenomenon and peculiarities of its development, namely: instructional leadership, leadership in research work, leadership as the formation of strategic vision and establishing business contacts, collegial and motivational leadership, fair and effective management, development and recognition of successful performance, formation and development of skills of establishing interpersonal relationships, etc.

British scientists R. Bolden, G. Petrov, and J. Gosling have suggested several ways of leadership distribution (Bolden, Petrov \& Gosling, 2008): formal (according to the hierarchical structure); pragmatic (situational delegation of authority to meet needs); strategic (based on the planned appointment of individuals to promote positive leadership development in educational institutions); gradual (increasing responsibility in accordance with a person's ability to perform leadership functions); cultural (leadership appears to extend naturally and is considered to be a part of the institutional culture).

J. MacBeath has provided a similar classification of distributed leadership perception, based on consideration of context features, objectives, organizational structures, personalities, etc. (MacBeath, 2005): formal (the evolution of financial and administrative authority within the department); pragmatic (discussion of responsibility sharing between colleagues); strategic (involvement of experts outside the university for enrichment with new ideas, knowledge and skills); incremental (progressive opportunities for activities and responsibilities, which presuppose active participation in committees, programs, projects, etc.); mercantile (people willingly participate in additional activities at the university and beyond it such as project management, membership in academic, professional, editorial board, counseling); cultural (leadership is organically perceived and spread like development of collegial research).

Therefore, as the analysis of scientific and educational literature testifies, distributed leadership is leadership that is performed by the department and university staff in England and Wales, and the main task of the manager-leader is to identify potential leaderssubordinates, develop their skills and knowledge necessary to implement certain activity that will lead to the achievement of goals and objectives of the educational institution. In our case, it is a process that occurs among university and support staff, and is based on 
leadership qualities of individuals to improve the performance of each member of an academic institution, and thus at improving the work of the department and the university as a whole.

\section{CONCLUSIONS}

The fundamentals of leadership in educational sphere are formed by comprehensive integration of theories of philosophy, sociology, psychology, pedagogy and management (trait theory and theory of charismatic leadership, behavioral, situational, process theories, theory of life cycle, theory of transformational, transactional, command leadership, customer oriented leadership, distributive leadership). Leadership in higher education of England and Wales implies the process of applying leaders' influence to followers, the efficient use of available resources, systems and procedures to meet the objectives of the organization and execution of its tasks. Its implementation involves attracting numerous university staff to manage the development of higher education in England and Wales in order to ensure the leading role of the university in the knowledge society.

The educational sphere is characterized by the use of distributed type of leadership, and its basic forms are formal, strategic, incremental, mercantile and cultural leadership. The application of distributed leadership in education has several drawbacks (fragmentation, lack of clarity in defining the employee's role, slow decision making, variation in individual capacity) and benefits (rapid response, transparency, convenience, teamwork).

Prospects for future research include studying the peculiarities of leadership implementation at universities of England and Wales; the standard system of academic leadership; the development of training programs for leader-managers, leader-pedagogues and leader-scientists in pre-service education; forms, methods and models of leaders' professional development in the sphere of higher education.

\section{REFERENCES}

1. Astin, A. \& Astin, H. (2000). Leadership reconsidered: Engaging higher education in social change. Battle Creek, MI: W. K. Kellogg Foundation, p. 106.

2. Blake, R. \& Mouton, J. (1972). The managerial grid: Key orientations for achieving production through people. Houston, TX: Gulf Publishing Company, p. 340.

3. Bolden, R., Petrov, G. \& Gosling, J. (2008). Developing collective leadership in higher education. Final report. LFHE, Centre for Leadership Studies, University of Exeter, p. 80 .

4. Bolman, L. \& Deal, T. (2008). Reframing organisations: Artistry, choice and leadership. San Francisco: Jossey-Bass, p. 512.

5. Ferren, A. (2004). Leadership through collaboration: The role of the chief academic officer. Lanham, MD: Rowman \& Littlefield Publishers, Inc., p. 328.

6. Fiedler, F. \& Garcia, J. (1987). New approaches to effective leadership: Cognitive resources and organisational performance. New York: Wiley, p. 240.

7. Hersey, P., Blanchard, K. \& Johnson, D. (2007). Management of organisational behaviour. Upper Saddle River, NJ: Prentice Hall, p. 837.

8. House, R. \& Dessler, G. (1974). The path-goal theory of leadership: Some posthoc and a priori tests. In: Hunt, J. \& Larsons, L. (Eds.). Contingency approaches to leadership. Carbondale, IL: Southern Illinois University Press, p. 29-55.

9. Gunter, H. (2001). Critical approaches to leadership in education. Journal of Educational Enquiry. Volume 2, Issue 2, p. 94-108. 
10. Leithwood, K. \& Levin, B. (2005). Assessing school leader and leadership programme effects on pupil learning: conceptual and methodological challenges. Research report 662. Nottingham: Department for education and skills, p. 55.

11. MacBeath, J. (2005). Leadership as distributed: a matter of practice. School Leadership and Management. Volume 25, Issue 4, p. 349-366.

12. Manz, C. \& Sims, H. (1980). Self-management as a substitute for leadership: A social learning theory perspective. The Academy of Management Review. Volume 5, Number 3, p. 361-367. p. 256 .

13. McGregor, D. (2005). The Human Side of Enterprise. New York: McGraw-Hill,

14. Méndez-Morse, S. (1992). Leadership characteristics that facilitate school change. Austin, TX: Southwest Educational Development Laboratory, p. 63. p. 288 .

15. Ramsden, P. (1998). Learning to lead in higher education. London: Routledge,

16. Stogdill, R. \& Coons, A. (Eds.). (1957). Leader behaviour: Its description and measurement. Columbus, OH: Bureau of Business Research, Ohio State University, p. 168.

17. Weber, M. (1997). The theory of economic and social organisation. New York: Free Press, p. 436.

18. Yukl, G. (1999). An evaluation of conceptual weaknesses in transformational and charismatic leadership theories. The Leadership Quarterly. Volume 10, Issue 2, p. $285-305$. 